\title{
IMPACT OF NITRIFICATION INHIBITOR APPLICATION ON THE NEMATODE COMMUNITY IN DAIRY PASTURE SOIL
}

\author{
L.T. AALDERS and N.L. BELL \\ AgResearch, Private Bag 3123, Hamilton, New Zealand \\ Corresponding author:lee.aalders@agresearch.co.nz
}

\begin{abstract}
Use of the nitrification inhibitor dicyandiamide (DCD) on New Zealand dairy farms is increasing in an attempt to minimise nitrate losses to ground water from urine patches. To study the impact of DCD on soil nematodes, samples were collected from a field trial in Waikato where $2.7 \mathrm{~kg} / \mathrm{ha}$ was applied on 11 occasions over 12 months, and total nematodes and the nematode community analysed. Of the nematode families, genera and indices calculated, only populations of plantfeeding Pratylenchus (lesion) nematodes were significantly different between DCD treated and untreated plots. These results suggest that frequent, small applications of DCD over a single year had no major effect on the nematode community from bulk soil.
\end{abstract}

Keywords: Nematode fauna, maturity index, enrichment index, structure index, Pratylenchus.

\section{INTRODUCTION}

Dairy farming is an important part of New Zealand's agricultural landscape with the increases in dairy cattle numbers and land area in milk production forecast to continue (MAF 2007). Nitrate leaching from agricultural land into groundwater and waterways is a growing environmental concern (Di \& Cameron 2002a), and nitrogen deposited by animal urine patches is a major source for nitrate leaching in grazed pasture systems (Ledgard et al. 1999; Di \& Cameron 2002a; Di et al. 2002).

The use of nitrification inhibitors such as dicyandiamide (DCD) is one management tool currently available that has been shown to reduce nitrate loss to groundwater (Cookson \& Cornforth 2002; Di \& Cameron 2002b, 2005). DCD works by inhibiting the oxidation of ammonium by ammonium oxidising bacteria (AOB) (Amberger 1989). Ammonium is less prone to leaching, being more readily bound to soil particles and is also available for plant uptake. DCD applied at 7.5 or $10 \mathrm{~kg} / \mathrm{ha}$ has resulted in dry matter increases of approximately 30\% (Di \& Cameron 2002b; Moir et al. 2007).

The effect of DCD on soil biota other than AOB has been little studied. Soil nematode community structure has been utilised as an effective indicator of environmental change (Yeates et al. 1993; Bongers \& Ferris 1999) and this paper investigates the impact of DCD application on soil nematodes.

\section{METHODS}

Samples were taken from an established grazed field trial being conducted at an experimental dairy farm near Hamilton on Horotiu sandy loam (Watkins 2007). The trial consisted of two treatments, control and DCD, with ten replicates of each in a randomised plot design. The twenty $4 \times 4 \mathrm{~m}$ plots were in two rows of ten with guard strips of $0.5 \mathrm{~m}$ between plots and a $1 \mathrm{~m}$ guard strip between rows. DCD was applied by a knap-sack sprayer 3 days after grazing, or at approximately 3 week intervals during periods of longer grazing rotations, from January to November 2006 at a rate of $2.7 \mathrm{~kg}$ DCD/ha. Further details can be found in Watkins (2007). 
Composite soil samples ( $2.5 \mathrm{~cm}$ diameter to $75 \mathrm{~mm}$ depth) were collected from each plot on 1 December 2006, 6 days after the last DCD application. Nematodes were extracted from a $100 \mathrm{~g}$ field moist sub-sample using a modified White and Hemming tray method over $72 \mathrm{~h}$ (Bell \& Watson 2001). Total nematode numbers were estimated using a Doncaster dish (Doncaster 1962), and they were then preserved in $4 \%$ boiling formaldehyde solution before a sub-sample (ca 100 nematodes) was taken to determine nematode community structure. This sub-sample was transferred to a $76 \times 50 \mathrm{~mm}$ glass slide using an Eppendorf pipette (with the tip cut so that the internal diameter of the tip was ca $3 \mathrm{~mm}$ ), and sealed under a $45 \times 45 \mathrm{~mm}$ coverslip using wax. Nematodes were identified using a microscope with interference contrast lighting at $400 \times$ magnification. Four nematode community indices, Bacterial/Bacterial+Fungal (Yeates \& Bird 1994), $\Sigma$ MI (sum of maturity and plant parasite index) (Yeates 1994), enrichment index and structure index (Ferris et al.2001), were calculated. The latter three indices include the use of a coloniser-persistor scale (1-5) to classify the life-history of nematode families. Nematodes in c-p 1 have traits consistent with very short life cycles and resistant stages (colonisers), while c-p 5 are longer-lived and are susceptible to environmental disturbance (persistors) (Bongers \& Bongers 1998).

For all nematode taxa and indices, the standard error and significance of the difference between control and DCD plots were determined using ANOVA on untransformed data.

\section{RESULTS AND DISCUSSION}

There were no significant differences between the control and DCD treatments for the taxa analysed in this study, with the exception of Pratylenchus $(\mathrm{P}<0.05$; Table 1$)$. Nitrogen amendments, and more specifically their ammonia breakdown products, have been shown to reduce plant parasitic nematode numbers either by direct nematicidal effect (Rodriguez Kabana 1986) or by enhancing naturally occurring biological controls, such as nematode-trapping fungi (Stirling 1991; Stirling et al. 2005), but the quantities required tend to be phytotoxic. Given that DCD had no effect on any of the other taxa, it is not clear why there were significantly lower numbers of Pratylenchus present in the DCD treatment. The lack of effect on bacterial feeders appears to reflect the lack of significant differences in AOB, DCD utilising bacteria or total culturable bacteria between treatments from the same soil (U. Sarathchandra, unpubl. data), although DCD is also a source of $\mathrm{N}(67 \%)$ (Rodgers et al. 1985) that could be used by soil micro-organisms (Hauser \& Haselwandter 1990; Schwarzer et al. 1998).

The $\Sigma$ MI was lower $(\mathrm{P}<0.10$; Table 1) for the DCD treatment than for the control. Values for this index decrease with decreasing environmental stability such as caused by soil disturbance or enrichment (Bongers 1999). The increased enrichment index value in DCD plots, although not significant, is also suggestive of soil enrichment. Cheng et al. (2008) found that the $\Sigma$ MI was lower and the enrichment index higher in turf grass amended with increased nitrogen inputs. The other two indices calculated did not differ between DCD and control.

Watkins (2007) found that DCD in the soil sampled here had a half life of 2.9 days and had completely disappeared by 19 days post application. This could be due to microbial breakdown or leaching or a combination of both. There were significantly higher levels of ammonium and lower levels of nitrate in the DCD treatment when pooled across the duration of the trial (+14 and $-17 \%$ respectively), but no significant differences in these levels for the individual November and December samplings (Watkins 2007). This suggests that small differences in ammonium and nitrate in the DCD plots at sampling did not result in observable differences in bacterial populations or nematode community composition. In one of the few studies examining the effect of DCD on nematodes, Magesan et al. (2000) found that the addition of DCD to municipal wastewater applied to soil cores did not have a significant effect on nematode populations. Similarly, Hua et al. (2006) found no significant effect on nematode communities when a slow release urea amended with DCD and a urease inhibitor was applied to soil. In this study, the bulking of 
TABLE 1: Mean abundance of feeding groups of nematodes, per $100 \mathrm{~g}$ of field moist soil, and indices calculated for the nematode community in soil from control and DCD plots.

\begin{tabular}{llrrrr}
\hline Feeding Group & Family or Genera & c-p & Control & DCD & SED $^{2}$ \\
\hline Plant & Helicotylenchus & 3 & 68 & 42 & 26.1 \\
& Heterodera & 3 & 50 & 40 & 18.3 \\
& Meloidogyne & 3 & 30 & 23 & 14.8 \\
& Paratylenchus & 2 & 638 & 724 & 265.8 \\
& Pratylenchus & 3 & 268 & 133 & $58.2 *$ \\
Plant associated & Tylenchidae & 2 & 738 & 773 & 145.8 \\
Fungal & Aphelenchus & 2 & 89 & 39 & 34.5 \\
& Aphelencoides & 2 & 376 & 421 & 53.2 \\
& Diphtherophora & 3 & 4 & 9 & 6.8 \\
Bacterial & Tylencholaimus & 4 & 43 & 20 & 16.2 \\
& Cephalobidae & 2 & 928 & 786 & 118.6 \\
Omnivore & Rhabditidae & 1 & 904 & 1073 & 270.3 \\
Total nematodes & Prismatolaimus & 3 & 32 & 30 & 20.8 \\
Indices & Dorylaimidae & 4 & 45 & 48 & 20.5 \\
& & & 4262 & 4190 & 388.2 \\
\hline & Bacterial/Bacterial+Fungal & & 0.783 & 0.786 & 0.032 \\
& EMI & & 3.98 & 3.78 & $0.10 \dagger$ \\
& Enrichment Index & 70.4 & 77.4 & 5.19 \\
& Structural Index & 23.3 & 21.4 & 5.33 \\
\hline
\end{tabular}

${ }^{1}$ Coloniser-persister value (Bongers \& Bongers 1998).

$2 *$ and $\dagger$ denote $\mathrm{P}<0.05$ and $\mathrm{P}<0.10$ respectively.

soil samples within plots may have also masked any spatial effects of urine patches where DCD is likely to be having its greatest effect on soil chemical and biological properties. Ritz et al. (2004) found nitrogen patches had a significantly positive effect on microbial biomass but a significantly negative effect on microbial functional diversity.

In laboratory experiments, it has been found that the DCD utilising bacterium, identified as Arthrobacter sp., could completely metabolise DCD, in the presence of urine, in soil within 4 days at $20^{\circ} \mathrm{C}$ (U. Sarathchandra, unpubl. data). Mean soil temperatures measured at $10 \mathrm{~cm}$ depth in the field from which the current samples were taken were approximately $16^{\circ} \mathrm{C}$ in November and December. It is possible, then, that the DCD was largely metabolised by the time the current samples were taken, 6 days after DCD application. Although this may explain the lack of significant differences in bacterial numbers between DCD and control plots (U. Sarathchandra, unpubl. data), if nematodes were feeding on DCD-metabolising bacteria there would be a time lag before the number of nematodes increased in response to the increase in bacteria.

Whether or not this trial was sampled too early to observe an effect of the November application of DCD on nematodes, the fact that there were no significant differences between DCD and the control suggests that repeated applications of DCD over a one year period did not cause an effect in bulk soil samples on the nematode taxa other than Pratylenchus analysed in this study. A pot trial is currently under way to examine the temporal effects of DCD in urine patches by measuring soil chemical and biological properties in urine-amended or untreated soil. 


\section{ACKNOWLEDGEMENTS}

The authors thank Natalie Watkins for allowing us to sample her trial, Upali Sarathchandra for collecting soil samples and Neil Cox for statistical analysis. The research was funded by the Foundation for Research, Science and Technology Contract C10X0232.

\section{REFERENCES}

Amberger A 1989. Research on dicyandiamide as a nitrification inhibitor and future outlook. Communications in Soil Science and Plant Analysis 20: 1933-1955.

Bell NL, Watson RN 2001. Optimising the Whitehead and Hemming tray method to extract plant parasitic and other nematodes from two soils under pasture. Nematology 3: $179-185$.

Bongers T 1999. The Maturity Index, the evolution of nematode life history traits, adaptive radiation and cp-scaling. Plant and Soil 212: 13-22.

Bongers T, Bongers M 1998. Functional diversity of nematodes. Applied Soil Ecology 10: 239-251.

Bongers T, Ferris H 1999. Nematode community structure as a bioindicator in environmental monitoring. Trends in Ecology \& Evolution 14: 224-228.

Cheng Z, Grewal PS, Stinner BR, Hurto KA, Hamza HB 2008. Effects of long-term turfgrass management practices on soil nematode community and nutrient pools. Applied Soil Ecology 38: 174-184.

Cookson WR, Cornforth IS 2002. Dicyandiamide slows nitrification in dairy cattle urine patches: effects on soil solution composition, soil $\mathrm{pH}$ and pasture yield. Soil Biology and Biochemistry 34: 1461-1465.

Di HJ, Cameron KC 2002a. Nitrate leaching in temperate agroecosystems: sources, factors and mitigating strategies. Nutrient Cycling in Agrosystems 46: 237-256.

Di HJ, Cameron KC 2002b. The use of a nitrification inhibitor, dicyandiamide (DCD), to decrease nitrate leaching and nitrous oxide emissions in a simulated grazed and irrigated grassland. Soil Use and Management 18: 395-403.

Di HJ, Cameron KC 2005. Reducing environmental impacts of agriculture by using a fine particle suspension nitrification inhibitor to decrease nitrate leaching from grazed pastures. Agriculture Ecosystems \& Environment 109: 202-212.

Di HJ, Cameron KC, Silva RG, Russell JM, Barnett JW 2002. A lysimeter study of the fate of N-15-labelled nitrogen in cow urine with or without farm dairy effluent in a grazed dairy pasture soil under flood irrigation. New Zealand Journal of Agricultural Research 45: 235-244.

Doncaster CC 1962. A counting dish for nematodes. Nematologica 7: 334-336.

Ferris H, Bongers T, de Goede RGM 2001. A framework for soil food web diagnostics: extension of the nematode faunal analysis concept. Applied Soil Ecology 18: 13-29.

Hauser M, Haselwandter K 1990. Degradation of dicyandiamide by soil bacteria. Soil Biology \& Biochemistry 22: 113-114.

Hua JF, Jiang Y, Liang WJ 2006. Response of nematodes in a Hapli-Udic Argosol to urea amended with urease and nitrification inhibitors. Pedosphere 16: 428-434.

Ledgard SF, Penno JW, Sprosen MS 1999. Nitrogen inputs and losses from clover / grass pastures grazed by dairy cows, as affected by nitrogen fertilizer application. Journal of Agricultural Science 132: 215-225.

MAF 2007. Situation and outlook for New Zealand agriculture and forestry (August 2007). Available from: http://www.maf.govt.nz/mafnet/rural-nz/statistics-andforecasts/sonzaf/2007/page-18.htm (accessed 27.04.08).

Magesan GN, Williamson JC, Yeates GW, Lloyd-Jones AR 2000. Wastewater C:N ratio effects on soil hydraulic conductivity and potential mechanisms for recovery. Bioresource Technology 71:21-27. 
Moir JL, Cameron KC, Di HJ 2007. Effects of the nitrification inhibitor dicyandiamide on soil mineral $\mathrm{N}$, pasture yield, nutrient uptake and pasture quality in a grazed pasture system. Soil Use and Management 23: 111-120.

Ritz K, McNicol JW, Nunan N, Grayston S, Millard P, Atkinson D, Gollotte A, Habshaw D, Boag B, Clegg CD, Griffiths BS, Wheatley RE, Glover LA, McCaig AE, Prosser JI 2004. Spatial structure in soil chemical and microbiological properties in an upland grassland. FEMS Microbiology Ecology 49: 191-205.

Rodgers GA, Wickramasinghe KN, Jenkinson DS 1985. Mineralization of dicyandiamide labelled with ${ }^{15} \mathrm{~N}$, in acid soils. Soil Biology \& Biochemistry 17: 253-254.

Rodriguez Kabana R 1986. Organic and inorganic nitrogen amendments to soil as nematode suppressants. Journal of Nematology 18: 129-135.

Schwarzer C, Auer B, Klima J, Haselwandter K 1998. Physiological and electron microscopial investigations on syntrophic dicyandiamide degradation by soil bacteria. Soil Biology \& Biochemistry 30: 385-391.

Stirling GR 1991. Biological control of plant parasitic nematodes - progress, problems and prospects. CABI, Wallingford. $282 \mathrm{pp}$.

Stirling GR, Wilson EJ, Stirling AM, Pankhurst CE, Moody PW, Bell MJ, Halpin N 2005. Amendments of sugarcane trash induce suppressiveness to plant-parasitic nematodes in a sugarcane soil. Australasian Plant Pathology 34: 203-211.

Watkins NL 2007. The ability of nitrification inhibitors to decrease denitrification rates in dairy farm soils. M.Sc thesis, University of Waikato, Hamilton. 126 pp.

Yeates GW 1994. Modification and qualification of the nematode Maturity Index. Pedobiologia 38: 97-101.

Yeates GW, Bird AF 1994. Some observations on the influence of agricultural practices on the nematode faunae of some South Australian soils. Fundamental and Applied Nematology 17: 133-145.

Yeates GW, Bongers T, De Goede RGM, Freckman DW, Georgieva SS 1993. Feeding habits in soil nematode families and genera - An outline for soil ecologists. Journal of Nematology 25: 315-331. 